\title{
Security Evaluation of Land Ecology in Dong Sheng District during 2005-2014
}

\author{
Rui yan $\mathrm{Wu}$ \\ Geographical sciences Department \\ Inner Mongolia Normal University \\ Hohhot, 010022, CHINA \\ 1362607775@qq.com
}

\author{
Ming Zhao, Rui ping Zhou \\ Geographical sciences Department \\ Inner Mongolia Normal University \\ Hohhot, 010022, CHINA \\ zmingjs@163.com,rpzhou@126.com
}

\begin{abstract}
On the basis of Press-State-Response framework model to build land ecological security assessment index system, this paper takes Dong Sheng district as the case, applied the difference value method, by the use of entropy weight to determine the weight, the land ecological security index were calculated, and then evaluated land ecological security of Dong Sheng district During 2005-2014. The results show that comprehensive value of land resources ecological security was 0.3919 in 2008, while it is 0.3496 in 2011, the land ecological safety is in a "sensitive level", which is in "good grade" in 2014, at the value of 0.5674 , with an obvious increase. In all comprehensive assessment indexes, the Land ecological pressure index has highest rate of contribution, which is indicating that the improvement of land ecological security of Dong Sheng is mainly rely on land desertification rate and urbanization rate.
\end{abstract}

Keywords-land ecological security evaluation; index system; Dong Sheng District

\section{INTRODUCTION}

The land ecological security is a stage that the structure of land ecological system, of which composition is organic and inorganic material, is not destroyed, at the same time, the quality and quantity of land ecological system's service can sustainably satisfy humans demands ${ }^{[3]}$. But with the increasing use on land resources and human activity accompanied by unreasonable land use pattern, has a serious of environmental problems such as forest vegetation cover has reduced; soil pollution; water loss and soil erosion; desertification of land and so on, these growing ecological environmental issues influencing our daily life seriously, restricting the development of social economy ${ }^{[7]}$. Thus, to progress land ecological security study becomes particularly important, of which main research method is land ecological security comprehensive evaluation. Land ecological security evaluation means an assessment on land ecological system's structure, function, worth and ecoenvironmental quality ${ }^{[10]}$.

The article, considered dong sheng as study area, develops and builds a set of evaluation index system based on the PressState-Response framework model and entropy weight method which is used to determine the weight. Thereby, figure out integrated values towards land ecological security of urban region, at last do the evaluation and analysis of the health or dangerous situation of urban land ecosystem.

\section{RESEARCH AREA, RESEARCH METHODS AND DATA SOURCES}

\section{A. Overview on Dongsheng District}

Dongsheng district, as the economy, science and technology, culture, transportation and information center of Ordos city, is located in the southwest of the Inner Mongolia Autonomous Region, Central part of the Ordos Plateau. The geographical coordinates of east longitude 109 degrees $08^{\prime} 04^{\prime \prime}-110^{\circ} 23^{\prime} 11^{\prime \prime}$, north latitude $39^{\circ} 30^{\prime} 42^{\prime \prime}-39^{\circ} 58^{\prime} 44^{\prime \prime}$, it is also one of the city's core area with its city's largest built area, the most perfect functional facilities and the highest degree of economic activity. The study area possesses $2512.3 \mathrm{~km}^{2}, 60.12$ ten thousands population. The topography is high in west and low in east, it can be divided into two areas. To the east is hilly-gully region with the altitude of $1269 \sim 1584.6 \mathrm{~m}$; the west area is Corrugated plateau area, the topography is relative slow, the west, north, east is a little high, south central is low, looks like basin. It is an extension of $\mathrm{Mu}$ Us Desert, of which the Wind erosion and desertification is serious.

\section{B. Research methods}

The article set and build land ecological security evaluation factors with regional characteristics at the basis of P-S-R framework model proposed by organization for economic cooperation and development. And using entropy weight method to measure index's weight, finally get to land ecological security comprehensive evaluation of dongsheng district.

\section{Data resources}

The research data are mainly from Dongsheng District's Statistical Bulletin of the National Economic and Social Development (2005-2014), Dongsheng statistical yearbook (2005-2014), Final database of land change survey (2005-2014) and land ecological environmental quality data, Window of Dongsheng- The official website of government, data provided by statistics department and environmental protection office.

\section{EVALUATION METHOD OF LAND ECOLOGICAL SECURITY IN DONG SHENG DISTRICT}

\section{A. Selection of evaluation factors of land ecological security}

The selection of evaluation factors is related to the whole evaluation process and the rationality of the results. Therefore, in the construction of evaluation index system of land ecological security, we should consider the regional social and economic development, local characteristics and the feasibility 
to quantitative analysis, but also consider the impact and representation the evaluation index may play a part in all aspects of regional nature, economy and social culture. In this paper, 22 indicators are selected to establish the evaluation index system of ecological security of land (Table 1) based on the pressure-state-response (PSR) framework model. The selected security indicators are divided into positive and negative trend indicators, which are denoted by "+" and "-". The bigger the value of positive safety trend index is, the better the land ecological security situation is, and the value of the negative safety trend index is bigger, which indicates that the land ecological security situation is worse.

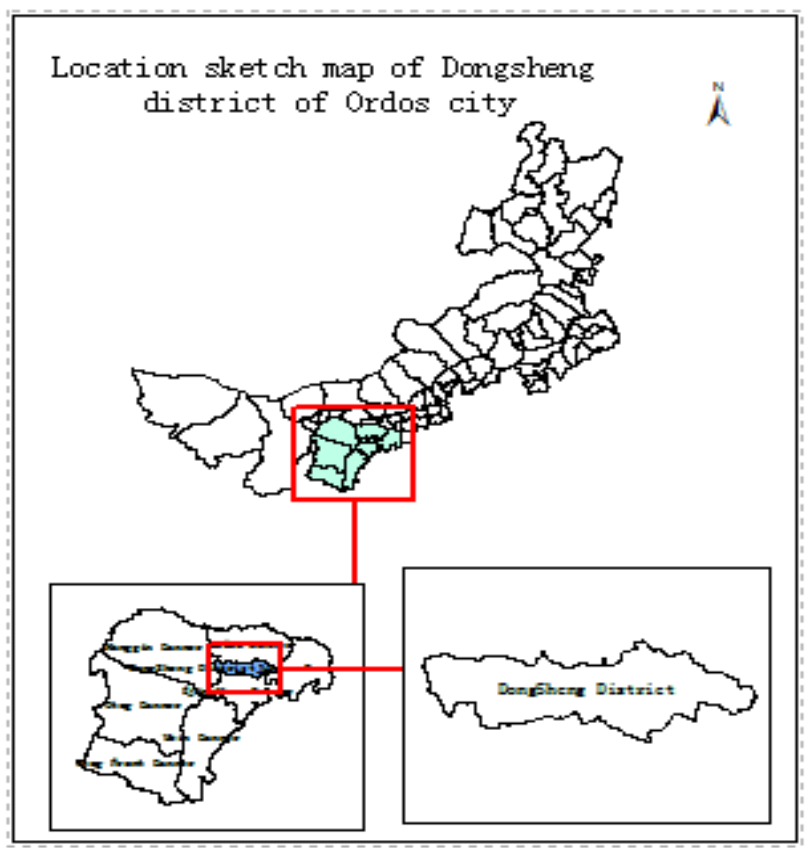

Fig. 1. Location sketch map of Dongsheng district

TABLE I. INDEX SYSTEM AND WEIGHTS OF LAND ECOLOGICAL SECURITY ASSESSMENT OF DONGSHENG DISTRICT

\begin{tabular}{|c|c|c|c|c|c|}
\hline \multirow{2}{*}{$\begin{array}{l}\text { Target } \\
\text { layer } \\
\text { A }\end{array}$} & \multirow{2}{*}{$\begin{array}{l}\text { Standard } \\
\text { Layer } \\
\text { B }\end{array}$} & \multirow{2}{*}{$\begin{array}{l}\text { Factor } \\
\text { Layer } \\
\text { C }\end{array}$} & \multicolumn{3}{|l|}{ Index layer D } \\
\hline & & & Index content & $\begin{array}{l}\text { Security } \\
\text { trend }\end{array}$ & weight \\
\hline \multirow{8}{*}{$\begin{array}{l}\text { A } \\
\text { Land } \\
\text { Ecologi } \\
\text { cal } \\
\text { security }\end{array}$} & \multirow{4}{*}{$\begin{array}{l}\text { Land } \\
\text { ecological } \\
\text { pressure } \\
\text { B1 }\end{array}$} & $\begin{array}{c}\mathrm{C}_{1} \\
\text { population } \\
\text { pressure }\end{array}$ & $\begin{array}{l}\text { D1 Population density } \\
\text { D2 Mechanical growth rate of population } \\
\text { D3 Natural growth rate of population }\end{array}$ & $\begin{array}{l}- \\
- \\
-\end{array}$ & $\begin{array}{l}0.03 \\
0.03 \\
0.03\end{array}$ \\
\hline & & $\begin{array}{l}\quad \mathrm{C}_{2} \\
\text { Land pressure }\end{array}$ & $\begin{array}{l}\text { D4 Raw coal (carbon) production } \\
\text { D5 Land desertification rate }\end{array}$ & $\begin{array}{l}- \\
-\end{array}$ & $\begin{array}{l}0.04 \\
0.08\end{array}$ \\
\hline & & $\begin{array}{l}\mathrm{C}_{3} \text { Social Economic } \\
\text { pressure }\end{array}$ & $\begin{array}{l}\text { D6 Economic density } \\
\text { D7 Urbanization rate }\end{array}$ & $\begin{array}{l}+ \\
+\end{array}$ & $\begin{array}{l}0.03 \\
0.06\end{array}$ \\
\hline & & $\begin{array}{l}\mathrm{C}_{4} \\
\text { Environmental } \\
\text { pollution pressure }\end{array}$ & $\begin{array}{l}\text { D8Total discharge of waste water } \\
\text { D9Total discharge of SO2 } \\
\text { D10Annual mean precipitation } \\
\text { D11 two or more excellent days in Full } \\
\text { year }\end{array}$ & $\begin{array}{l} \\
- \\
+ \\
+\end{array}$ & $\begin{array}{l}0.04 \\
0.03 \\
0.04 \\
0.03\end{array}$ \\
\hline & \multirow{2}{*}{$\begin{array}{l}\text { Land } \\
\text { ecological } \\
\text { Status } \\
\text { B2 }\end{array}$} & $\begin{array}{l}\mathrm{C}_{5} \text { land } \\
\text { quality }\end{array}$ & $\begin{array}{l}\text { D12Land expropriation price } \\
\text { D13Proportion of unused land area }\end{array}$ & $\begin{array}{l}+ \\
+\end{array}$ & $\begin{array}{l}0.06 \\
0.07\end{array}$ \\
\hline & & $\begin{array}{c}\mathrm{C}_{6} \text { land } \\
\text { Use structure }\end{array}$ & $\begin{array}{l}\text { D14Area proportion of forest land } \\
\text { D15Proportion of grassland area } \\
\text { D16Proportion of construction land area } \\
\text { D17Proportion of water area }\end{array}$ & $\begin{array}{l}+ \\
+ \\
- \\
+\end{array}$ & $\begin{array}{l}0.03 \\
0.03 \\
0.03 \\
0.12\end{array}$ \\
\hline & \multirow{2}{*}{$\begin{array}{l}\text { Land } \\
\text { ecological } \\
\text { Respond } \\
\text { B3 }\end{array}$} & $\begin{array}{c}\mathrm{C}_{7} \text { social Economic } \\
\text { respond }\end{array}$ & $\begin{array}{l}\text { D18Per capita GDP } \\
\text { D19Sewage treatment rate } \\
\text { D20New green area }\end{array}$ & $\begin{array}{l}+ \\
+ \\
+\end{array}$ & $\begin{array}{l}0.04 \\
0.03 \\
0.05\end{array}$ \\
\hline & & $\begin{array}{l}\mathrm{C}_{8} \text { System } \\
\text { resilience }\end{array}$ & $\begin{array}{l}\text { D21 protection of Environmental } \\
\text { investment for GDP } \\
\text { D22protection of Third industry for GDP }\end{array}$ & $\begin{array}{l}+ \\
+\end{array}$ & $\begin{array}{l}0.06 \\
0.04\end{array}$ \\
\hline
\end{tabular}


B. Determination of index weight, standard values and safety index

1) DATA standardization

To standardize the original data matrix, evaluate land ecological security of $m$ kinds of evaluation factors of specific area in $\mathrm{n}$ years. The original index data matrix as in:

$$
X=\left[\begin{array}{cccc}
X_{11} & X_{12} & \ldots & X_{1 n} \\
X_{21} & X_{22} & \ldots & X_{2 n} \\
\ldots & \ldots & \ldots & \ldots \\
X_{m 1} & X_{m 2} & \ldots & X_{m n}
\end{array}\right]
$$

Applying the difference value method to standardize all indexes, different indexes have different standardized formula. When evaluation index is positive index, $y_{i j}=\left(X_{i j}-\min x_{j}\right) /\left(\max x_{j}-\min x_{j}\right)$, when it is negative index, $y_{i j}=\left(\max x_{j}-x_{i j}\right) /\left(\max x_{j}-\min x_{j}\right)$. In standardized formula, min $x_{j}$ means min value of index values; $\max x_{j}$ is $\max$ value; $X_{i j}$ is original value of $\mathrm{j}$ index in $i$ year. The Normalized matrix is $Y$, $Y=\left(y_{i j}\right)_{n^{*} m} y_{i j} \in[0,1], y_{i j}$ is Standardized value of original value.

TABLE II. LAND ECOLOGICAL SECURITY VALUE OF DONGSHENG DISTRICT DURING 2005-201

\begin{tabular}{|c|c|c|c|c|}
\hline \multirow{2}{*}{ year } & \multicolumn{3}{|c|}{ Security value } & $\begin{array}{c}\text { Comprehensive value of } \\
\text { ecological security }\end{array}$ \\
\cline { 2 - 5 } & Land ecological pressure & Land ecological status & Land ecological respond & 0.5040 \\
\hline 2005 & 0.2003 & 0.2200 & 0.0837 & 0.3919 \\
\hline 2008 & 0.2566 & 0.0958 & 0.0395 & 0.3496 \\
\hline 2014 & 0.1538 & 0.1022 & 0.0936 & 0.5674 \\
\hline
\end{tabular}

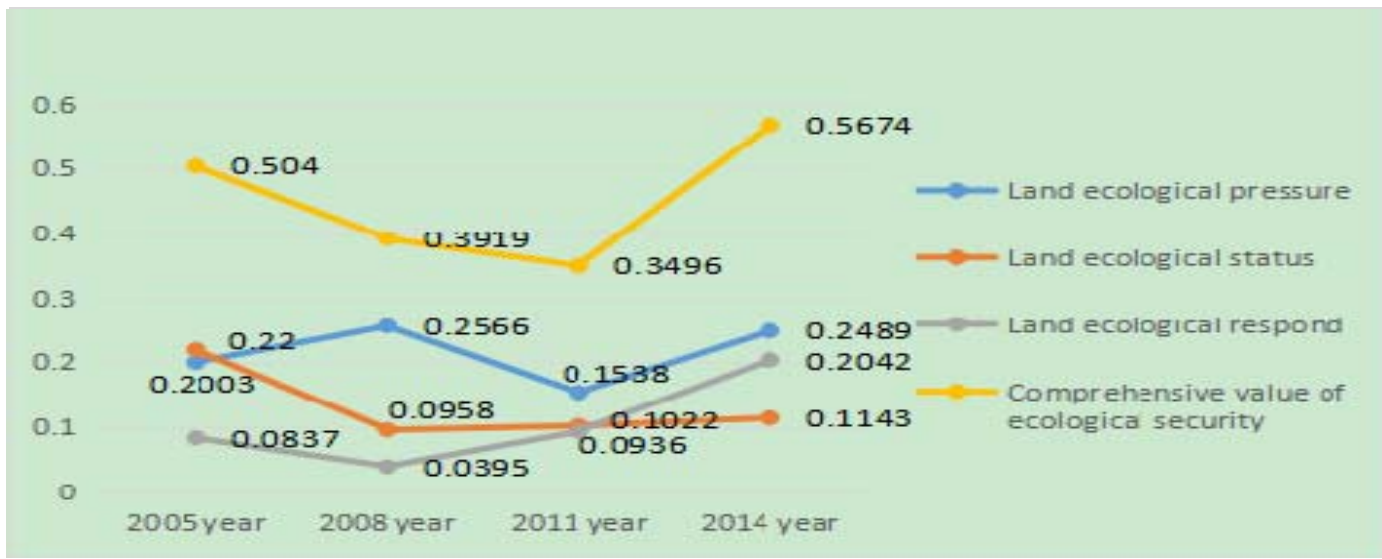

Fig. 2. Trend of land ecological security of Dongsheng District during 2005-2014

TABLE III. CRITERION OF LAND ECOLOGICAL SECURITY COMPREHENSIVE EVALUATION

\begin{tabular}{|c|c|c|c|}
\hline $\begin{array}{c}\text { Safe } \\
\text { Zone(T) }\end{array}$ & grade & states & System characteristics \\
\hline $0<\mathrm{T} \leq 0.15$ & I & $\begin{array}{c}\text { Serious } \\
\text { level }\end{array}$ & $\begin{array}{r}\text { The land ecological environment is very bad, the structure of the land ecosystem is not } \\
\text { complete, ecological restoration and reconstruction is very difficult. }\end{array}$ \\
\hline $0.15<\mathrm{T} \leq 0.3$ & II & Risk level & $\begin{array}{c}\text { The land ecological environment is bad, the structure of the land ecosystem is destroyed, its } \\
\text { service function is greatly degraded and environment is difficult to recover after external } \\
\text { disturbance. }\end{array}$ \\
\hline $0.3<\mathrm{T} \leq 0.5$ & III & $\begin{array}{c}\text { Sensitive } \\
\text { level }\end{array}$ & $\begin{array}{c}\text { The land ecological environment is poor, the structure and function of ecosystem has been } \\
\text { destroyed, but it still can maintain the basic function. }\end{array}$ \\
\hline $0.5<\mathrm{T} \leq 0.8$ & IV & $\begin{array}{c}\text { Good } \\
\text { grade }\end{array}$ & $\begin{array}{c}\text { The land ecological environment is good, the land ecosystem structure is relatively complete, } \\
\text { and service function is still good, the interference can generally be restored, the possibility of } \\
\text { occurrence of ecological disasters is small. }\end{array}$ \\
\hline $0.8<\mathrm{T} \leq 1$ & $\mathrm{~V}$ & $\begin{array}{c}\text { Safety } \\
\text { grade }\end{array}$ & $\begin{array}{c}\text { The land ecological environment is good, the land ecosystem structure is complete, the land } \\
\text { ecosystem service function is perfect, and the function is strong, seldom happen ecological } \\
\text { disaster. }\end{array}$ \\
\hline
\end{tabular}

2) Determination of index weight

The analysis steps in a problem of $m$ indexes, $n$ evaluation objects are: (1)Calculate the proportion of $j$ index at $i$ evaluated objects, the formula as: $f_{i j}=y_{i j} / \sum_{i=1}^{n} y_{i j} \cdot$ (2)Calculate index 
information entropy, $H_{j}=-k \sum_{i=1}^{n}\left(f_{i j} \times \ln f_{i j}\right), \mathrm{i}=1,2,3, \ldots, \mathrm{n} ; \mathrm{j}$ $=1,2,3, \ldots, \mathrm{m}$. And $k=1 / \ln n$ (assume that when $f_{i j}=0$, $\left.f_{i j} \ln f_{i j}=0\right)$. (3)Calculate redundancy of information entropy $d_{j}=1-H_{j}$. (4)Determine the index weight $W_{j}=d_{j} / \sum_{j=1}^{n}\left(1-H_{j}\right),\left(\mathrm{w}_{\mathrm{j}} \in[0,1] ; \sum_{j=1}^{n} w_{j}=1\right)$.

\section{3)Calculation of land ecological security value}

The mathematical model of land ecological single index:

$$
S_{i}=W_{j}^{*} Y_{i j}
$$

In formula: $S_{i}$ is land ecological security value; $W_{j}$ is weight coefficient of $\mathrm{j}$ index; $Y_{i j}$ is standardized value of $\mathrm{j}$ index in i year. Although the security value of single index can reflect the land ecological security situation of dongsheng in several different aspects, we still need to do comprehensive calculation to indexes if we want to reflect the land ecological security level definitely. The mathematical model of the comprehensive value of the index of land ecological security is:

$$
T=\sum_{i=1}^{n}\left(W_{j} \times Y_{i j}\right)
$$

In formula: $\mathrm{T}$ is the comprehensive security value of land ecological; $W_{j}$ is weight of each index; $Y_{i j}$ is standardized value of $\mathrm{j}$ index in $\mathrm{i}$ year; $\mathrm{n}$ is the amount of index.

According to the formula and related data above, the security value of each individual index is calculated separately(table 3 ), and at this basis, work out pressure value of land ecological security, Land ecological security status, response value of land ecological security and comprehensive value of land ecological security(table2, Fig. 2).

\section{ANALYSIS ON ASSESSMENT RESULT}

According to land ecological security comprehensive calculated value, I have designed criterion of land ecological security comprehensive evaluation(in Table3), the data range of comprehensive security value $(0 \sim 1)$ was divided into 5 security levels in this table. The greater the security value, the better the situation of land ecological security is, otherwise the worst, and then describes the system features of these 5 levels.

\section{A. Evaluation on pressure safety}

We can see from table 4 , the state of changes of the land ecological pressure index of dongsheng is increase at first and then decrease, increase from 0.2003 in year of 2005 to 0.2566 in 2008, indicating that the situation of ecological pressure land resources facing is going better (it is a negative index, the smaller the value, the greater the ecological pressure). Such as urbanization rate (positive index, the bigger, the better)is increase from $89.8 \%$ (2005)to $92.1 \%(2008)$, has increase $2.3 \%$. Economic density (positive index) is increase from 542.51million yuan to 1543.24. The chief result is the transformation of traditional forms of land use because of improvement of urbanization level, which is making clear that human's overall pressure on land resources is weakened relatively. In the year of 2011, land ecological pressure is enlarging sharply. Between the years of 2011 and 2014, various index have improve obviously, owe to a serious of measures taken by the government and the public. The contribution rate of land ecological pressure index to land ecological security is increase from $39.7 \%$ in 2005 to $43.87 \%$ in 2014 .

\section{B. Evaluation on state security}

The state security index is stay in improving stage, it's to say that present situation of land resource ecological security is continue going better even though it has a little reduction between 2005 and 2008.Among these, land quantity stage change from 0.07 in 2005 to 0.06 in 2014 , so as to the contribution, from $13.89 \%$ to $11.9 \%$. The land use state has great changes, from 0.15 (2005) decline to $0.0786(2008)$, which is due to marked increase in proportion of construction land(0.19-0.98) and the apparent decrease in the proportion of water area(17.95-3.37). Contribution of land ecological state index to land ecological security down to $20.14 \%$ of 2014 from $43.65 \%$ in 2005 .

\section{Evaluation on response security}

The response index of land resources ecological security in Dongsheng district has been continuously improved, showing a rapid upward trend, which increased from 0.0837 in 2005 to 0.2042 in 2014, an increase of 0.1205 . View on response index, the social and economic response index increased from 0.0237 in 2005 to 0.16 in 2014 , in the social and economic response index, the changes of GDP per capita, sewage treatment rate, the per capita green area are 40725 to $153502,93.1 \%$ to $95 \%$, 6.53 to 14.84 square meters between 2005 and 2014.Dongsheng has new green area of 1 million 420 thousand square meters, green area of constructed area is 29 million 650 thousand square meters in 2014, and ratio of green space reached $38 \%$. The overall function of the city has become more and more perfect, as well as urban living environment has gradually improved. Through the analysis, it can be concluded that the level of economic development, the improvement of investment in environmental protection and the adjustment of industrial structure will contribute greatly to the improvement of the ecological environment of land resources.

\section{Evaluation on comprehensive security}

The composite index of ecological security of land resources in Dongsheng area drop from 0.5040 in 2005 down to 0.3919 in 2008 , but from 2011 to 2014 years showed a rising trend. The main reason is the economic construction, the increase of population and the exploitation of coal mining cause ecological environment status of Dongsheng district severely damaged before 2011.But since 2011, with the proportion of industrial construction industry in the regional economy reduce, proportion of wholesale, retail trade and tourism industry increase, and as a result of several measures, such as vigorously carry out the upgrading of the industrial structure, eliminate big pollution industry turn to develop less pollution, new effective green industry intensive, make the land security comprehensive value of the Dongsheng district rose to 


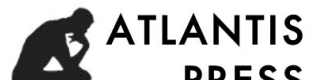 PRESS}

a better state. According to table 4, the pressure index of land ecological security has the highest contribution rate; it shows that the land resource ecological security status of Dongsheng area mainly depends on the improvement of land desertification rate and urbanization rate etc. (known from weights value in table 1 ).

\section{CONCLUSION AND DISCUSSION}

Dongsheng district, as the economy, science and technology, culture, transportation and information center of Ordos city, the extension area of $\mathrm{Mu}$ Us Desert, there are serious problems like wind erosion and desertification, so land resources ecological problems is particularly important, because of its geological characteristics. The evaluation result shows that comprehensive safety values were $0.3919,0.3496$ in 2008 and 2011, land ecological security belongs to "sensitive level", but in 2014 has an obvious improvement, belongs to the "good "level, at the value of 0.5674 .The calculated results are close to the actual situation, which proves that the evaluation method used in this paper has a certain reference value. The land resource ecological security is the basis and important content of ecological security is an important index which is used to determine the sustainable land use, effective distribution of resources, sustainable development. Therefore, we should attach importance to environmental protection in the process of social and economic development, and evaluate ecological security regularly to study influence factors in different periods under different conditions and the ecological security status.

\section{REFERENCES}

[1] Xin xiang Cao, Zhi yong Guo, Han chao Luo. 2004.Study on Ecological Security of Regionally Sustainability Utilization of Land Resources[J]. Journal of Soil and Water Conservation. Vol. 18 No. 2 Apr. "In Chinese".

[2] Jun Guang Wang, Zhi Zhong Zhao, Guang Ru Zhao, Zhong Wei Zhang. Evaluation on Land Ecological Security in HaiNan Island[J]. Journal of ANHUI AGR. i Sc. i , 2010, 38(8):4215-4218.'In Chinese".

[3] LI Yu ping, CAI Yun long. Security Evaluation of Land Ecology in Hebei Province[J]. ACTASCIENTIARUM NATURALIUM UNIVERSITATIS PEKINENSIS On Line, 2007, Vol. 2, No. 3, Sept. 30."In Chinese".

[4] Pei Ting Ting, Chen Ying, Zhao Ya nan, Wang Daojun, Liu Shu an Evaluation on the Ecological Security of Bai yin City Based on P-S-R Model[J]. Chinese Agricultural Science Bulletin, 2014, 30(2):215221."In Chinese".

[5] Li Ling, hou shu tao, zhao yue, zheng xu ling. Evaluation And Forecast of Land Ecology Security of He Nan Province Based on P-S-R Mode. research of soil and water conservation[J]. 2014, vol. 21, no. 1 feb . "In Chinese".

[6] Zhang Jun yi, Su Weici, Zhang Jie. 2011.Study of Land Resources Ecological Security Evaluation in the Case of Chongqing During 2000 [J]. AREAL RESEARCH AND DEVELOPMENT. Vol, 2009, 30 No. 4 Aug. "In Chinese".

[7] Yang Chun, He ke run, Li can bin. Land Ecological Security Evaluation of HuNan Province. "In Chinese".

[8] CAI Tai Yi, MA Shou Chen, Lv Peng, Wang Rui. . Evaluation of Land Ecological Security in Jiaozuo City Based on the PSR Model[J]. Hubei Agricultural Sciences. 2014, Vol53 No. 6 Mar. "In Chinese".

[9] Zhang Jun Yi, Su Wei Ci, Zhang Feng Tai. Regional land ecological security evaluation in the case of Chongqing Three Gorges Reservoir ecological economy area based on the PSR model. [J]. China Environmental Science, 2011, 31(6):1039 1044."In Chinese".

[10] Dong Fei, Song Ge. Evaluation of urban land ecological security in Harbin A Cheng district as an example [J]. Journal of land and resources information. "In Chinese". 